\title{
Romans 1:18-32 amidst the gay-debate: Interpretative options ${ }^{1}$
}

\author{
Jeremy Punt \\ Department of Old \& New Testament \\ University of Stellenbosch
}

\begin{abstract}
The prominence of Romans 1:18-32 in the gay-debate is the subject of various and wide-ranging opinions as far as the most adequate interpretation of this passage. This contribution puts the debate about the text into perspective by surveying some recent alternative opinions on its meaning. It is established that two particular matters are most important in Romans 1:18-32 and the past and current debate on its interpretation: the argument according to "nature" and the nature of the infringement or error (Rm 1:27).
\end{abstract}

\section{INTRODUCING THE ISSUE}

The pivotal biblical text on the topic of same-gender relationships in the New Testament is often considered to be Romans 1:18-32 (cf recently Johnson 2006:56,135; Nolland 2000:32-57), in particular by those who hold what can be broadly referred to as an "anti-homosexual position", believing that homosexuality is inherently sinful, that homoerotic acts are depraved or that same-sex relationships should be prohibited. ${ }^{2}$ Some of those holding an antihomosexual position are willing to admit that Romans 1 "is neither a general discussion of sexual ethics, nor an explicitly prescriptive admonition about the sexual behavior appropriate for Christians" (Hays 1986:187); yet, Romans 1 is nevertheless seen by some in an almost abstract way as the definite, biblical position on homosexuality.

\footnotetext{
${ }^{1}$ Edited section of a paper presented at the annual NTSSA congress, 2-5 April 2007, Stellenbosch.

${ }^{2}$ The variety of positions held in the Christian community on biblical references to homoerotic acts, contemporary homosexuality or same-sex relationships is well described in e g Holben (1999) and Johnson (2006); for a range of interpretative positions of Romans 1:26-27, cf Nolland (2000). The focus of this article is not to provide another taxonomy of Christian positions on homosexuality but is more limited, attending to Romans1:18-32 as a theological argument rather than instruction on sexual morality; different interpretations of the homoerotic acts referred to in Romans 1 are briefly discussed.
} 
The current discussion on Romans 1 necessarily takes places against the background of the gay-debate found in most mainline churches and which is a debate about human sexuality, but which is simultaneously to a large extent also the unfortunate symptom of a much larger debate about the status and role of the Bible and its interpretation (cf Bates 2004). Furthermore, given the general reluctance in Christian circles to discuss matters of the body (corporeality), gender and sexuality and the failure to do so amidst the pervasiveness and global manifestation of sexism, ${ }^{3}$ more than fleeting attention is required for the way in which the Bible is used and appropriated in matters of sexuality.

The reference to homoerotic activities in Romans 1:26-27 has in the past been interpreted in many ways, taken to refer in its extreme versions for the socalled plain or literal sense of condemning "homosexuality", to other and generally more nuanced positions on dismissing perverse and abusive homoerotic liaisons or Roman, imperial sexual excesses. While no attempt is made here to provide a complete summary of such positions and counterarguments, the following presents a brief synopsis of important explanations offered of Paul's statement, starting with the traditional position.

\section{DOMESTICATING ROMANS 1:26-27 AS ANTI- HOMOSEXUAL PROOF TEXT}

The traditional understanding of Romans 1 includes "homosexuality" in the inventory of moral depravity found in 1:29-32, indeed, puts it at the top of the list (so Holness 1992:24). "The traditional understanding of the apostle Paul's teaching concerning homosexuality is an unambiguous 'no"' (Holness 1992:25). The Romans 1 text is seen as condemnation of any and all homosexual relations and activities. Explanations of Romans 1 tend to focus on the meaning of $\phi \dot{\sigma} \sigma \iota \varsigma$ (nature), because Paul seems to privilege this concept. ${ }^{4}$ The broader concern of Paul in Romans 1 is taken as the apostle's disquiet that

\footnotetext{
${ }^{3}$ Sexism is a cross-cultural phenomenon and is present in various (most?) cultures, even if in different ways. It is mostly chauvinistic in origin and can be observed in attitudes and decisions based on the premise of women's inferiority, physically, mentally, sexually or otherwise, and found in practices insisting upon the lesser worth of females; their need for less if any formal education; seeing them as the property of their fathers, brothers or husbands; excluding women from civil and human rights; viewing their abuse at the hands of men either permissible or at best excusable; and viewing their economic productivity to be below that of their male counterparts. Sexism penetrates social structures, shapes social attitudes and values, and oppresses significant numbers of humanity, literally one-half of the human race.

${ }^{4}$ Its polyvalent nature is, however, clear from the following: it refers to the natural heritage of people (Jews) in Galatians 2:15 and Romans 2:27; in Romans 2:14 to acts that are in accordance with customs and traditions; to qualities of persons and things in Galatians 4:8; to the education and social customs within a certain cultural context.
} 
people place themselves and their desires before God and worship of him. In the end, Paul is seen as addressing the sin of human egocentric selfishness and self-aggrandisement, and swapping God for inferior gods: people act

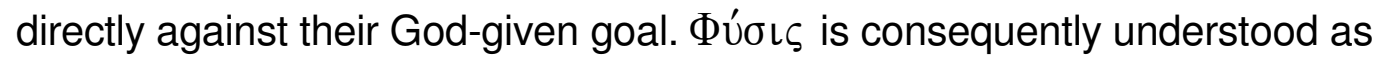
more or less equivalent to God's intended purpose for people and with the world. $^{5}$

The anti-homosexual use of Romans 1 generally harbours a thinly veiled affirmation of heteronormativity in what is claimed to be divine opposition to homosexuality. ${ }^{6}$ De Young's attempt is poorly disguised by claims to the (inappropriate) influence of worldview in interpretation - while, ironically, insisting that the particular religious convictions to which he subscribes, defines the totality of Christian existence, belief and morals. Some authors go as far as arguing that Paul addressed same-sex relation from a trans-cultural perspective of God's created order (Malick 1993:340) which obviates the need to investigate Greco-Roman or Jewish backgrounds. And therefore, authors argue (e g Smith 1996:247-250) that Paul's criticism is directed at sexual phenomena of which Paul knew the same variety as we do today, and not sexual models where there is some distance between ancient times and today (cf also Thiselton 2004:186).

In the case of Romans 1, a theologised natural order is sometimes evoked. The description of homoerotic acts in Romans 1 should be read in light of the broader issue about idolatry. Idolatry is essentially a denial or lie about the truth which is God since in Jewish thought the opposite of truth is not error but the lie, and therefore homoeroticism (Novak uses "homosexual relations") is spiritual perversion in the sense that men relate to their alter ego's (other men) as do women. "[T] his celebration of absolute masculinity or absolute femininity belies the biological truth of the essentially intersexual relatedness attested to by the fact that the sexual organs and the organs of procreation are the same" (Novak 2005:116-122, esp 118).

The traditional interpretation of Romans 1 as anti-homosexual text tends to interchange what Paul says about idolatry and homoerotic acts. Paul claims that rebellion against God is manifested, among others, in unnatural sexual

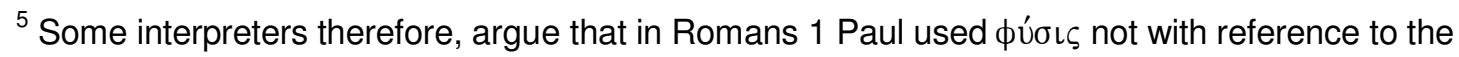
"natural" but rather in an "essential" way: natural sexual relations is between male and female through male and female genitals, and homosexual sexual activity runs counter to this pattern (Louw 1980:110-115). Such an essentialist approach fails, however, to appreciate social convention and its role in identity formation.

${ }^{6}$ Contrary to his interest in discovering "the truth about homosexuality" and wanting to avoid "vitriolic hateful treatment that some have directed against homosexuals in the name of Christ", De Young's has already found the answer: "If this volume makes no contribution beyond explaining why God opposes the homosexual lifestyle, a worthwhile goal will have been accomplished" (De Young 2000:12).
} 


\section{Romans 1:18-32 amidst the gay-debate}

liaisons, those threatening to destroy the hierarchical and patriarchal first century world. The claim cannot be reversed without doing an injustice to Paul and perverting his argument: cause (rebellion) and effect or result (homoerotic activities) cannot simply be interchanged, also not on the premise that since rebellion is a specific sin then that specific sin is as good as rebellion. In fact, good reasons exist why this would not constitute a valid exchange. Firstly, it confuses cause and effect, and creates the dangerous misunderstanding that if you address the consequences, that you then are in fact also addressing the cause as well. An important consideration against viewing Romans 1 as first and foremost proscribing homoeroticism is that the standard Jewish view on sin or transgression entailed that if it was not atoned for in ways prescribed in the Bible, it would be punished, whether in this world, by sickness, suffering, or death, or in the world to come (Sanders 1992:40-47). In Romans 1, however, homoeroticism is already the consequence of sin, the failure to acknowledge God as God. Secondly, it does an injustice to the real issue which the texts are addressing and distracts from Paul's main point and the issue which he raised, namely rebellion against God. ${ }^{7}$ Thirdly, it creates the impression that a particular manifestation of the results of rebellion encapsulates the rebellion fully, which has over the centuries contributed to the fabrication of homophobia and to some extent, also contributed to growing negative view of sexuality in various forms of early Christianity. And, finally, it unnecessarily complicates the ability to address or rectify the situation - such redress obviously needs to start with the cause rather than the effect.

Various forms of uneasiness with the traditional interpretation of Romans 1 as anti-homosexual text have given rise to an equally wide range of counter readings, elaborating on one or more neglected elements of the text, or addressing interpretative choices.

\section{RECENT ALTERNATIVE INTERPRETATIONS OF ROMANS 1:18-32}

Alternative interpretive possibilities offer varying degrees of opposition to the traditional condemnation of "homosexuality" in Romans 1, either in terms of "orientation", or - and found much more often - in terms of homosexual activities. In the interest of paying attention to the Romans 1 as theological argument, my overview will focus on pivotal elements in the text.

\footnotetext{
${ }^{7}$ So also then, to argue that lesbigay couples who do seek to honor God necessarily are to be viewed in a different light (Johnson 2006:136), misses the point: homoerotic acts are (some of) the consequences of not acknowledging God, not its cause.
} 


\subsection{Unacceptable cultic practice}

Paul cautions against a large scale cultic practice of homosexual acts. Such an explanation fits well with the broader context of disavowing and disallowing idolatrous practices, where homosexuality was a prime component of other cultic practices including temple prostitution. This explanation ties in with the Pauline argument based on perception and "common sense", where an appeal for the natural fitting together of male and female is made. ${ }^{8}$

\subsection{Heterosexuals engaging in homoerotic acts}

Paul is criticising heterosexual people who engages in homosexual activities ${ }^{9}$ which are "against their nature" (Boswell; cf Wink 1999:36), and his criticism is not directed against people who are homosexual by nature, and for whom homosexual relations and activities would be "natural". ${ }^{10}$ Furthermore, Paul is in any case criticising "reckless, shameless, profligate, promiscuous behaviour", not the contemporary "committed, loving homosexual relationships" (cf Stott 1984:307).

\subsection{Lack of self-mastery}

The statements against homoeroticism are presented as part of a wider discourse on God's reaction against human idolatry which manifests also in human lack of control over their bodies. Female homoeroticism impinges upon the honour of the husbands of these women, leaving the men emasculated. "Because they do not worship God, this is the shameful state to which God has reduced them. The message in Romans is not about morality but about faith, about the difference between life in Christ and life without, in Israel redeemed and outside Israel" (White 1995:23).

Moreover, and although a typical Jewish concern with a generalised sense of the Gentile life, contemporary philosophers and the Stoics in particular emphasised the need for self-mastery (' $(\mathcal{\gamma} \kappa \rho \alpha \tau \in \dot{i} \alpha)$ and deplored the lack of self-mastery $(\dot{\alpha} \kappa \rho \alpha \sigma i \alpha)$ as foolishness - a similar stance as found in Romans 1:21-28 (Stowers 2003:529).

\footnotetext{
${ }^{8}$ This explanation is questioned by Wright (1993:413) who finds the basis of Pauline criticism in the "immoral character of homosexuality" as illustrated by the accompanying list of vices; Wright fails, however, to note the structure of and assumptions on which the argument is built, leaving Romans 1 as a rather indiscriminate compilation of ideas.

${ }^{9}$ In the modern debate, often referred to as "perverts" (who have a heterosexual orientation, yet engages in homosexual activities) as in distinction to "inverts" (who have a homosexual orientation).

${ }^{10}$ Criticism of this view entails accusations that it implies an "atomistic" reading of the passage, as well as the improbability of a distinction made between heterosexual and homosexual orientation made by Paul (Wright 1993:413).
} 


\section{4 "Nature/natural" as unstable category}

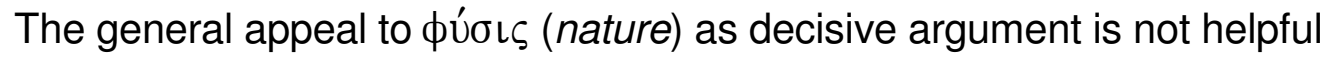
because in other instances where the same argument is employed (e g 1 Cor 11:13-15, regarding hairstyles; $\mathrm{Rm} 11: 17-24$ esp 24 , on the unnaturalness of the inclusion of Gentiles among the believers), biblical interpreters generally reject its validity. That which is considered natural is generally socio-culturally determined - common sense - and therefore not a fixed but rather inherent unstable category that can change over time in a particular community and might simultaneously be similar across different, contemporary communities.

\subsection{Inequality of homoerotic acts}

Paul criticises the very unequal nature of homoerotic acts, which inevitably included practices of (cultic) prostitution, as well as the unequal ones in society such as slaves and young boys (pederasty) ${ }^{11}$ In particular, Paul's criticism is directed at the widely practiced pederasty ${ }^{12}$ (Scroggs 1983), which was built on unequal relationships involving active, older men with social power and passive, young boys. Even when such relationships were played out with a benefactorclient schema, these relationships were quite often criticised and ridiculed by contemporary philosophers and others. ${ }^{13}$

From a different perspective and focussing on his Jewish background, Paul is believed to have continued the criticism of one person dominating another, particularly if both were men; this and not the condemnation of "homosexual acts" is also the overriding sentiment as it was already expressed

\footnotetext{
${ }^{11}$ In this regard, Johnson (2006:123) also claims that biblical passages reject both intergenerational and status-defined homoeroticism, but not "egalitarian, covenantal relationships" because these are not addressed in the texts. The evidence provided by Smith (1996) shows that homoerotic acts went beyond pederasty but the examples mostly do not presuppose relationships based on equality (frequently involving slaves or prostitutes); no examples of "committed adult homosexual marriage" (Smith 1996:244) are provided.

12 “... the only model of male homosexuality was pederasty ..." (Scroggs 1983:130). Cf also e g Furnish (1979:52-83); Pregeant (1995: 407ff).

${ }^{13}$ Others have criticized Scroggs' position: Pregeant (1995:407ff) argues that 1 Cor 6 can still be explained according to pederasty, but not Romans which is more general and where the condemnation of homoerotic acts is assumed as part of corruption of the world. He sees the reasons for Paul's attitude as related to the exploitive nature of pederasty; Jewish scriptures; and the emphasis on ritual purity vs pollution according to a natural order argument. Coleman (1995:68) challenges Scroggs' contention that Romans 1:26 refers to pederasty only, claiming that Paul and the author of $1 \mathrm{Tm}$ made use of Leviticus concepts, rejecting "homosexuality" in general - however, it does seem speculative when Coleman argues, " $\ldots$ it is quite possible the specific form of homosexual behavior that New Testament writers would have come into contact most often. But this does not mean it was the only form they had in mind" (Coleman 1995:68). However, while Paul did seem to advance a more general portrayal of homoeroticism in Romans1, it does not rest on the nature/natural argument (so Westerholm 1997:30 n 25); unnatural here does not concern the age, status or position of the object choice - cf further below.
} 
in Genesis 9:20-28, Genesis 19, Judges 19 and Leviticus 20:13. Female homoeroticism is decried because it generates pleasure without regard for consequences and "what encourages the acquisition of virtue". However, changing perceptions about what is considered virtue or sin change, as Paul himself admits in Romans 14:13-23 regarding the consumption of meat sacrificed to idols (O'Grady 2003:100-101).

\subsection{Homoerotic acts as exaggerated sexual activity}

Romans 1 emphasised the result of $\sin$ in the form of elaborate and exaggerated sexual activities, contrary to what would be considered decent and proper, in short, conventional. Paul referred to same-sex sexual activities as commentary on the sexually overheated nature of the Roman Empire. Hellenistic-Jewish literature typically presented idolatry and sexual immorality as characteristic abominations of the gentile world, and in the case of Romans 1 probably captured a shared sense of moral revulsion from pagan converts in Rome about the sexual outrages of recent emperors ${ }^{14}$ which scandalised everyone in capital. Paul's focus is the moral bankruptcy of the imperial house (cf also Rm 1:29-31), which characterised conventional gentile morality: the passage is an inexcusable exaggeration but as reference to the horrors of imperial house, actually restrained (Elliott 1994:181-230).

More generally, W S Johnson (2006:45ff) refers to the "hedonistic sexual practices of the Roman world" - adding to that "certain cultural assumptions about proper male roles" - and also stresses the "passive-active asymmetry" of homoerotic acts in the Roman world (Johnson 2006:264 n15). Attentive to the typical strategy in ancient argumentation to denigrate your opponents and their practices through stereotyping, Paul's rather sweeping reference can be understood not as a reference to any particular group of individual but rather as a "crude sexual slur" in a rhetorically charged argument. Such a caricature would have resonated with Jew and Gentile alike in the context Paul addressed, but most importantly, functioned as illustration of the immorality and sexual chaos resulting from an unwillingness to honour God (Johnson 2006:7576).

\subsection{Homoerotic acts as culturally embedded}

Romans 1:18-32 must be read as a whole and the examples which illustrate the point ( $v v 26-28$ ) may not be divorced from the larger context of the pericope

\footnotetext{
${ }^{14}$ Tiberius had the island Capri made into sex colony full of male/female slaves; Caligula's self-deification did not exclude sexual predation which included incest; rape of dinner guests; and submitting himself to foreign hostages/prisoners; and Nero was reputed for rapes, brothel-keeping, incest with his mother, sexual submission to men and boys - his tutor, Seneca, remarked that he was another Caligula (Elliott 1994:181-230).
} 
which denounces idolatry as an expression of wilful stupidity seeing that God is clearly observable from nature. This stubbornness was punished by God through bestowing an essentially unclean culture upon the Gentiles, with the primary evidence to be found in same gender sexual activity. Since anal copulation was strongly prohibited in Jewish culture and with increasing popular Greco-Roman sentiment against homoeroticism ${ }^{15}$ under influence of Stoicism's insistence that the value of sex was largely procreational, Paul "could claim superiority for Jewish culture by the standards of the dominant culture itself" (Countryman 2003:172-173).

In this sense then Paul is not first and foremost concerned with homosexual or even sexual issues at all, but focused on divine retribution, which should be understood according to the cultural context and the broader, determining socio-cultural values such as honour and shame categories operative in the time.

\section{THE IMPORTANCE OF EXEGETICAL CHOICES IN READING ROMANS 1}

The arguments listed above all dwell to some extent on - if not depend upon a few interpretative choices, with the following two probably being pivotal in how Paul's argument is understood today:

\subsection{The "nature/natural" argument}

Paul's argument is heavily based on what is considered "according to nature", with "unnatural" referring to unconventional or out of the ordinary practices, actions contrary to accepted social practices. ${ }^{16}$ In contemporary literature, $\phi u ́ \sigma \iota \varsigma^{17}$ was generally used for two categories of meaning: origin or constitution, and secondly, in medical-technical and vulgar language with reference to the genitals. The reference to genitals should be read within the

\footnotetext{
${ }^{15}$ The gender of the subject or object of sexual desire was of little consequence in Greek discussions of natural sexuality (Balch 2003:268); Martin (1995:332-355) argues that it is equally inconsequential in Romans1. Natural was determined by hierarchical relations as far as partners were concerned, and moderation and self-mastery with regard to sexual activities.

${ }^{16}$ Such an interpretation is countered by the argument that the prominence of the theme of "divine creation" mitigates against an understanding of nature as anything but God's design; and, widespread homosexual relations and activities implied its toleration (as natural) in society (Wright 1993:413). However, tolerance is not the same as acceptance and justification, and Paul's position emerged from Hellenistic Jewish thought and custom where homosexual activity was not tolerated, within a Greco-Roman world with varying opinions amidst a (decreasing?) prevalence of homosexual relations - cf below.

17 'In the seven 'undisputed letters' of Paul, the adjective appears twice, and the noun ten times. Neither occurs in the Synoptics, and indeed hardly ever in the New Testament. As a typically Greek concept, it has no equivalent in the Hebrew Bible" (Szesnat 1995:40 n 12).
} 
Greco-Roman socio-cultural context where the misleading "natural relations"18

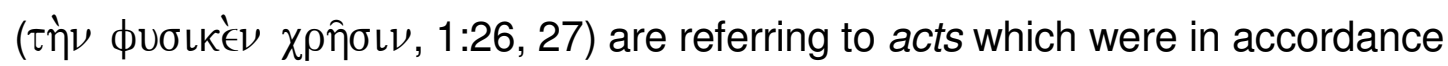
with the social hierarchy of society, the conventional or proper way of acting. Paul used "contrary to nature" or "unnatural" only with reference to actions ${ }^{19}$ as borne out by Paul's use of $\chi \rho \hat{\eta} \sigma \iota \varsigma$, and as reference to desire (Martin

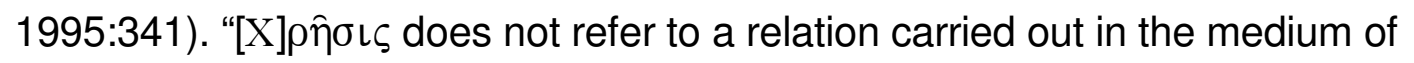
sexual pleasure but the activity of the desiring subject, usually male, performed on the desired object, female or male" (Frederickson 2000:199). The gender of the sexual partner is not as important as his/her social status and the sexual act have to conform to the "social status hierarchy" of the participants. Philo of Alexandria laments that "gender-bending" will result in "men appearing as women", which might be reflected in the "shameless acts"20 of Romans 1:27. In short, nature in the first century and in the twentieth century presupposes different cultural assumptions, worldviews and symbolic universes (Szesnat 1995:40). ${ }^{21}$ In fact, in Romans 1 the phrase "contrary to nature" is anachronistically interpreted as referring to the wrong object choice (Martin 1995: 332-355; cf Vorster 2000:119).

Greco-Roman homoeroticism should be understood within a context where sexual activity and penetration in particular was determined by gender, as well as by class and status (Crossan \& Reed 2004:264; cf Brooten 1996:14-17). Given the acceptance of female inferiority, her submission to the male constituted what was believed as natural and therefore appropriate, and it was not only homoerotic acts between females but also women performing oral sex on men - considered servile and degrading - or women assuming an active role in sex with men, which was considered abnormal or contrary to nature (cf Balch 2003:277-278), and therefore inappropriate. Especially from a

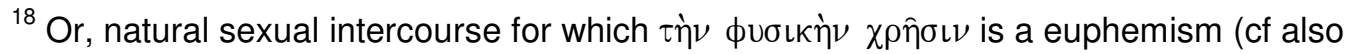
Szesnat 1995:39 n 8).

${ }^{19}$ Hamel (1984:124) refers to the prevalence of "action verbs": exchanging, abandoning, doing, perpetrating, committing. Cf below on desire. Schotroff (1995:39) focuses ov $\kappa \alpha \tau \in \rho \gamma \alpha \zeta o ́ \mu \epsilon \nu \mathrm{O}$ as sexual activity and relates the unnatural use of women's bodies "primarily to the avoidance of pregnancy and childbirth and only secondarily to lesbian sexuality".

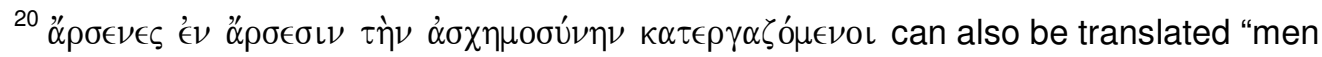

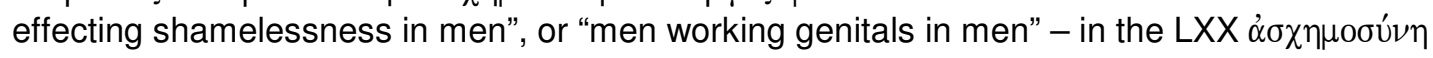
is a euphemism for genitals (e g Lv 18) (Szesnat 1995:39 $n$ 9; 43), as well as for genital nakedness and intercourse (Ex 20:26; cf Rv 16:15) (Swancutt 2004:64).

${ }^{21}$ Paul dealt with other issues within the early church also on basis on the "nature"-argument: ranging from extreme acts of courage to the perceived unnaturalness of eating meat; and, the length of women's and men's hair (1 Cor 11:14-15). While "both hair length and sexual behaviour are issues of gender" (Szesnat 1995:40-45; cf Stegemann 1993:163), it is clear Paul's claims are culturally rather than theologically informed. Paul could also not appeal to the OT in this regard, since Hebrew has no word for "nature" (Johnson 2006:82).
} 
Jewish moral perspective, where legitimate sex was explicitly heterosexual and thus to be found in marriage and aimed towards procreation, ${ }^{22}$ first century Greco-Roman sexual mores were caricaturised and frowned upon. ${ }^{23}$

The tensions and ambiguity of the liminal position of the Diaspora Jews can be traced also in the Pauline epistles. In an attempt to be faithful and true to Jewish religious convictions, which amongst others included the observance of certain customs, conventions and rituals, and at the same time absorb to an appropriate extent elements of the surrounding Hellenistic world which included subscribing to notions of universalism, meant that Diaspora Jews had to walk a tightrope between religious affiliation and socio-cultural accommodation. One important element in Philo, for example, was the focus on the universal, on the inhabited world or oikoumene which subordinated the particular, the concern of any specific city-state or polis to the "megalopolis" or big city which is the world. The world has a single polity and a single law, "the word or reason of nature (logos physeos)" (Roetzel 2003:60, referring to Philo, Joseph 29).

But the nature/natural-argument is to be used with greater care than is often found in anti-homosexual readings of Romans 1. Paul's argument on the inclusion of Gentiles in the people of God in Romans 9-11 is reliant upon the same contrast between what is natural ( $\kappa \alpha \tau \dot{\alpha} \phi \dot{\sigma} \sigma \nu)$ and what is unnatural $(\pi \alpha \rho \dot{\alpha} \phi \dot{v} \sigma \iota \nu)^{24}$ (e g Johnson 2006:98-99). By using the same language, and having God as the implicit author of the cutting and the grafting, it is God acting against nature and Paul defending his gracious nature without claiming it to be natural. ${ }^{25}$ Moreover, by the same token, the followers of God are expected to follow suit: to act contrary to nature! While it is not denied that

\footnotetext{
${ }^{22}$ Ward (1997:263-284) argues at length, with reference to Plato's Laws and Timaeus that the nature-argument was concerned with procreation that prescribed fixed gender roles (active/passive) and proscribed homoerotic acts, both concerned to regulate against sexual pleasure as dangerous and leading to evil.

${ }^{23}$ However, across the spectrum first-century sexuality was nevertheless male, aggressive and boundary-controlling, and normative sexual behavior was directly related to power and control, and as shown in the Augustan marriage laws, related to the regulation of female sexual expression and procreation among the elite (Crossan \& Reed 2004:261). The underlying presupposition was "biological dualism", which was centrally related to procreation: "It is therefore 'natural' biology that presupposes men to be active and women to be passive" (Schotroff 1995:38). "Nearly all extant Roman-period sources on female eroticism condemn it, defining it as monstrous, unnatural, diseased, and more" (Brooten 1996:191).

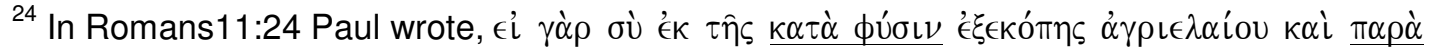

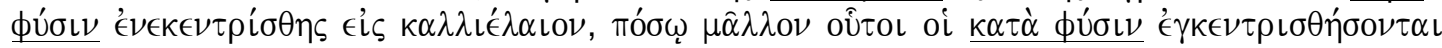

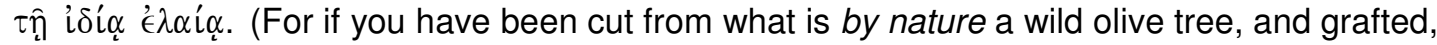
contrary to nature, into a cultivated olive tree, how much more will these natural branches be grafted back into their own olive tree, RSV).

25 "For God's ability, "contrary to nature", to graft wild branches into a cultivated tree assumes that the creator's power transcends even nature's generativity (White 1999:152).
} 
Paul together with the other Jews of the day would have - and indeed had reacted sharply against first-century, Greco-Roman homoeroticism, Paul however, at the same time, endeavoured to include the very same Gentiles, all of them $(\operatorname{Rm} 1: 5,7,16)$, into the covenant and people of God. Romans 1 wanted to accomplish little more than to posit the need for Gentiles to acknowledge and belief in God, on the grounds of a caricaturised portrayal of the decay of society without God. And while Paul's expectation of Gentiles who join the fold of the followers of Christ would entail a different morality and lifestyle (cf Rm 13:13-14), it was not one of rigid conformity to social and other conventions: as Paul explains in Romans 12, Christian morality is a matter of discernment from the heart and mind.

\subsection{What is the nature of the "wrongness"?}

A striking feature of the reference to homoerotic acts in Romans 1:24-26 is its presentation as consequence rather than origin of sin, and so the absence of any descriptions of same gender-sex as $\sin { }^{26}$ The descriptions boil down to impurity, social disgrace and Paul's idiosyncratic version of the Stoic concerns for nature and the natural: ${ }^{27}$ an "error" indeed (Rm 1:27). If the connection between Romans 1:27-27 and 1:28-32 is indeed secure, the strongest term used for describing same gender-sex is probably $\tau \dot{\alpha} \mu \grave{\eta} \kappa \alpha \theta \eta \dot{\eta} \kappa \nu \tau \tau \alpha^{28}$ ("things that are not fitting", 1:28), which was also typical "Greek-speaking Jewish polemic" (Countryman 2003:172-175). In fact, a number of different but (partially) interlinked concerns inform Paul's condemnation in Romans 1, ranging from the official, imperial to the more conventional, domestic contexts.

\footnotetext{
${ }^{26}$ Similar to other divine punishments meted out in the past, where the fall of humanity resulted in heavy labor and painful childbirth $\left(G_{n} 3\right)$ and where the Tower of Babel was punished with the multiplication of human languages (Gn 11:1-9), Romans1's admittedly pejorative language make no claims for either the essentially sinful nature of same gendersex, or that it deserves God's wrath (Countryman 2003:174) - this does not imply, however, that Romans1 assumes the Genesis account of the Fall! Romans1:29-32, of course, contains a general list of condemned vices.

${ }^{27}$ For a brief explanation why Stoicism presents a ready and legitimate comparison, cf Swancutt (2004:48-53). Engberg-Pedersen (2000:200-212) argues that three themes which correspond with Stoic thinking emerge in Romans1:18-32: failure of the required directness towards God (which in the Stoics' case would have reason); failure in "ethical" behaviour; and "the phenomenon that explains both, self-directedness" (Engberg-Pedersen (2000:200).

28 "Inappropriate acts" which in Stoic sensibility violated common decency of people as they inhabit their social worlds (Stowers 2003:535), or the "natural duties as citizens" which their minds, "totally enfeebled" through idolatry, have prevented them from performing (Swancutt 2004:65). This phrase is used only here in Paul, and only once elsewhere in the NT but with a different meaning (Countryman 2003:173, 221).
} 


\section{Romans 1:18-32 amidst the gay-debate}

In the first place, the broader socio-historical context of the contemporary, early Roman Empire with its focus on the restoration of public and private order and discipline, enforced through Augustus' strong laws on morals and marriage, ${ }^{29}$ all of which was supported by a "massive propaganda effort". ${ }^{30}$ Augustus was constantly portrayed as the best example of selfmastery, in contrast to his opponents; e g Cleopatra's main concern was depicted as her own sensual gratification, served by Anthony as her lovecrazed slave. In typical imperialist paternalism and self-justification, the Roman conquest and submission of other peoples were vindicated on the notion of the Roman rulers effecting self-mastery to the benefit of their subjects, ${ }^{31}$ and beyond what the subjects could accomplish on their own: "self-disciplined Rome rules subject peoples for their own good" (Stowers 2003:530-531).

While the strong heterosexual focus in theory if not in practice shows analogy to the heteronormativity of today, it was, secondly, the socio-cultural perception of sex, gender and sexuality that differed in many ways from conviction, convention and practice today - and Romans 1 therefore profits from a queer (que[e]rying) reading ${ }^{32}$ of Paul (Moore 1998:250-274). A study of contemporary authors exhibits an understanding of "homosexuality" which differs radically from modern perceptions, not the least because sexuality was not separated by a homosexual-heterosexual dividing line, but adhered to a boundary informed by social status and determined by activity and passivity (cf Stegemann 1993:164). Free-born males ruled the roost and asserted their masculinity through (sexual) activity, by penetration, in contrast to others being soft and therefore susceptible to be penetrated. Penetration was the role reserved for those lower down the social ladder regardless of their sex: women,

\footnotetext{
${ }^{29}$ The Augustan idea of constructing a new world and in fact, a new era, required its citizens not only to be married but also to bear offspring. Horace's hymn which was officially commissioned for the Seculum Games of 17 BCE underlines this concern: "Rear up our youth, O goddess, and bless the Fathers' edicts concerning wedlock and marriage-law, destined, we pray, to be prolific in new offspring" (Carm.Saec. 17-20; cf Crossan and Reed 2005:141). Cf Swancutt (2004:55 n $64)$.

${ }^{30}$ These laws were part of a broader programme initiated by Augustus to revitalise Rome and the Empire, probably for both his own advantage and securing his position, as well as for a more altruistic perspective of the benefit of the Empire (cf White 1999:116ff).

${ }^{31}$ With the Latin form of ' $\epsilon \sigma \in \beta \alpha \dot{\alpha} \sigma \eta \eta \sigma \alpha \nu$ (they worshipped, Rm 1:25 - a NT hapax legomenon) in nominal form being equivalent to Augustus, Jewett wonders whether this is subtle criticism upon the Roman Empire and emperor cult (Jewett 2000:228).

${ }^{32}$ Queer theory's own gestation has to be considered against the background of influences such as social constructionism ("queering") and the theoretical and political accommodation of the role of social dynamics and power play in sex and gender ("querying"). Cf Punt (2007).
} 
slaves, effeminate males, eunuchs, "barbarians", "captives" and so forth. ${ }^{33}$ "The reduction of sexual relations to the act of penetration enables sex to become a simple yet effective instrument for expressing hierarchical relations" (Moore 1998:271). Gender and social status in the first century, Greco-Roman world were interlinked, rendering "class-infused views of masculinity" (Moore 1998:266-7; cf Vorster 2000:103-124), and relegated femininity and women along with other non-dominant groups as subsidiaries to free men. In Romans 1 with its inversions (reversed gender hierarchy of female-male, and reversed gendered actions with women exchanging and men giving up), effeminate language is on the cards - with the loss of honour and implications of shaming involved for first-century readers. Contemporary binaries fail to address this situation, and require the queering of sex, gender and sexuality. ${ }^{34}$

A third, important context important in understanding Romans 1 is the socio-cultural world or symbolic universe of Paul which was heavily indebted to notions of clean and unclean. ${ }^{35}$ As a Jew Paul understood the world as orderly cosmos, classified and systematised so that everything, person, place and time could be categorised in terms of purity. Paul's strong words in Romans 1 deal with his concern with cultural purity, and not a moral matter, at least not in the first place (Countryman 1988; purity together with property and possession ${ }^{36}$ as governing values for sexuality in Jewish context, building on Mary Douglas' theory re purity). When it comes to the human body, wholeness was highly valued as much as bodily excretions were potentially dangerous sources of

\footnotetext{
${ }^{33}$ Others object to this description, e g "I must applaud recent studies that have shown unequal-status and active/passive aspects to be a culturally sustained component of an ancient world portrait of homosexuality. But interjecting equal-status or covenant into the equation fails to side-step the problem. The deepest issue for the biblical authors was the breaking of sexual boundaries between male and female". Webb's statement betrays his bias through his imposition of context-foreign material onto the biblical authors' frame of reference, claiming it as their theological position in abstraction while in effect discounting their own socio-cultural context, and the extent to which their context predisposed their theological understanding of human sexuality (Webb 2001:e g 251).

${ }^{34}$ For a brief glimpse of the wide range of $1^{\text {st }}$ century CE Greco-Roman medical (Epicurus, Celsus, Soranus and Galen) and theological and philosophical (including ascetics like the Therapeutae, Philo, Chaeremon) opinions about sexuality and appropriate sex, cf Balch (2003:266-268). A general uneasiness with sex is palpable, based on the possibility that sex might have power over men rather than that men preside over sex, and women.

${ }^{35}$ Neyrey (1990:54-55) lists according to semantic world fields 13 different ways in which purity and 7 different ways in which pollution was expressed in the New Testament, with the majority of these also found in the Pauline corpus, indicative of the importance of these concepts for Pauline thought.

${ }^{36}$ Berger (2003:232-239; esp 234-235) also refers to a number of instances where Paul dealt with sexuality in terms of property rights, and instances where Paul used "juristic genres" denoting a concern for believing receiving their dues. He concludes: "For Paul, sexuality is essentially a matter of property rights" (Berger 2003:239).
} 
pollution with flows of blood, menses, semen or pus designating it unclean, and putting it "out of place". Specific popular understandings of purity were important since they regulated full membership and participation within contemporary Jewish communities, and uncleanness received no sympathy or tolerance (Neyrey 1990:31-32).

Other socio-cultural influences can also be detected in Romans 1:18-32, as well as hybrid positions incorporating elements of several of the above were common, especially since Jews and Christians in different yet analogous ways entertained similar claims to both philosophy and self-consciousness, and also to self-mastery, which served them well within the Roman Empire. The link to typical Stoic concerns in Romans 1 - "Romans 1:24-27 is thoroughly consistent with Stoic denunciations of non-Stoic philosophers" (Swancutt 2004:65) shows for example how what was considered the false understanding of people's larger view of life was seen as the reason for passions and their inability to control passionate desire (Stowers 2003:535).

\section{CONCLUSION}

The nature of Paul's argument in Romans 1 suggests that it is in a certain way an elaborated version of the argument found in 1 Thessalonians (1 Th 4:3-6 in particular), and cannot simply be cited in arguing against homosexuality today. Paul is concerned about the purity of followers of Christ from Gentile stock and they should thus avoid the sexual practices of Gentiles who do not know God, inevitably practices in which people are wronged (Stowers 1994:97). Paul did not, however, provide specific directives for either lesbigays who know God or lesbigays in committed relationships that do not exploit anyone ${ }^{37}$ (cf Johnson 2006:135), because such identities were not readily available options ${ }^{38}$ in the first century CE.

A sexual ethic informed by perspectives from the New Testament challenges the assumptions which make reproductive sex into a norm. For

\footnotetext{
${ }^{37}$ The use of ${ }^{\prime} \epsilon \iota \theta u \mu i^{\prime} \alpha$ in negative sense as lustful desire (1 Th 4:5; Rm $6: 12 ; 7: 7,8 ; 13: 14$ ) but also in positive sense as good and even godly desire (1 Th 2:7; Phlp 1:23), underwrites the importance to make distinctions in the nature and practice of sexual actions (cf Johnson 2006:135).

${ }^{38}$ No indication of the wide-spread presence of long-term homoerotic relationships in the time of the NT exists - rather exceptions that proved the rule - and also hardly convincing evidence of egalitarian, loving, non-oppressive relationships. Importantly, neither can such exceptional instances then simply be taken as reference for the Romans 1:26-27, nor can the conclusion be avoided that where such long-term homoerotic relationships were negatively perceived, the negativity was underwritten by the what was seen as the transgression of the social norms regulating male (active, penetrating) and female (passive, being penetrated) roles re gender and sex, as well as by the physical impossibility to procreate.
} 
example, when Jesus or Paul talks about marriage, neither of them insists upon procreation "as a rational or functional justification" (Williams 2002:6). ${ }^{39}$ Sexual orientation or "constitutional" or "core" homosexuality was not considered options in ancient thinking about sexuality; neither were committed, caring same-sex relationships seriously contemplated in a context where homoerotic acts were necessarily conflated with "immorality, debauchery and licentiousness" (Johnson 2006:136). ${ }^{40}$ In short, Paul's argument in Romans 1 cannot be applied directly ${ }^{41}$ to what modern people know about homosexuality, as much as his instructions about hair lengths and dress codes are also considered inappropriate for direct appropriation today.

\section{Works consulted}

Balch, D L 2003. Paul, families, and households, in Sampley, J P (ed), Paul in the Greco-Roman world: A handbook, 258-92. Harrisburg, PA: Trinity Press International.

Bates, S 2004. A church at war: Anglicans and homosexuality. London: IB Tauris. Berger, $\mathrm{K}$ 2003. Identity and experience in the New Testament, tr by C Muenchow. Minneapolis, MN: Fortress.

Brooten, B J 1996. Love between women: Early Christian responses to female homoeroticism. Chicago: University of Chicago Press. (Chicago Series on Sexuality, History, and Society.)

Coleman, G D 1995. Homosexuality: Catholic teaching and pastoral practice. Mahwah: Paulist.

Crossan, J D \& J L Reed. 2004. In search of Paul: How Jesus's apostle opposed Rome's Empire with God's Kingdom: A new vision of Paul's words and world. New York: HarperSanFrancisco.

\footnotetext{
39 "If we are afraid of facing the reality of same-sex love because it compels us to think through the processes of bodily desire and delight in their own right, perhaps we ought to be more cautious about appealing to Scripture as legitimating only procreative heterosexuality" (Williams 2002:6).

${ }^{40}$ Which is not quite the same as Jewett's argument that Romans1 posits a heterosexual preference in the "aggressively bisexual society" of the $1^{\text {st }}$ century CE, to which some members of the early Christian communities may have been exposed as e $\mathrm{g}$ (former) slaves; coming full circle, however, he claims that in the modern predominantly heterosexual society "patterns of abuse and exploitation" may be different, requiring a re-evaluation of Romans1 but, in the end he backtracks because of what he calls "increasingly exploitative bisexual behaviour" and advocates holding up "the standard accepted so broadly in early Christianity (Jewett 2000:240-241).

${ }^{41}$ In any case, focussing in the debate on homosexuality on a few, single texts "fails to view sexuality as just one dimension of human relationship, embedded in a constellation of familial, interpersonal, and communal connections that shape, support, or deform it. Instead, sexuality is seen a peculiar problem for ethics, a discrete and troublesome domain requiring unique regulation" (Plaskow 2003:48).
} 


\section{Romans 1:18-32 amidst the gay-debate}

Countryman, W 1989. Dirt, greed and sex: Sexual ethics in the New Testament and their implications for today. London: SCM.

De Young, J B 2000. Homosexuality: Contemporary claims examined in light of the Bible and other ancient literature and law. Grand Rapids, MI: Kregel Publications.

Elliott, N 1994. Liberating Paul: The justice of God and the politics of the apostle. Maryknoll, NY: Orbis. (The Bible \& Liberation, vol 6.)

Engberg-Pedersen, T 2002. Paul and the Stoics. Louisville, KY: W J K.

Frederickson, D E 2000. Natural and unnatural use in Romans 1:24-27: Paul and the philosophic critique of Eros, in Balch, D L (ed), Homosexuality, science and the "plain sense" of Scripture, 197-222. Grand Rapids, MI: Eerdmans.

Furnish, V P 1979. The moral theology of Paul. Nashville, TN: Abingdon.

Hamel, E 1984. Scripture, the soul of moral theology, in Curran, C C \& McCormick, R A (eds), Readings in moral theology, no 4: The use of Scripture in moral theology, 105-133. New York: Paulist.

Hays, R B 1986. Relations natural and unnatural: A response to John Boswell's exegesis of Romans 1. Journal of Religious Ethics 14(1), 184-215.

Holben, L R 1999. What Christians think about homosexuality: Six representative viewpoints. North Richland Hills, TX: BIBAL.

Holness, P 1992. Homosexuality: A thorny issue re-examined. South African Baptist Journal of Theology, 23-35.

Hornsby, T J 2005. The gendered sinner in Romans 1-7, in Grenholm, C \& Patte, D (eds), Gender, tradition and Romans: Shared ground, uncertain borders, 14366. New York: T\&T Clark. (Romans Through History and Cultures Series.)

Jewett, $R$ 2000. The social context and implications of homoerotic references in Romans 1:24-27, in Balch, D L (ed), Homosexuality, science and the "plain sense" of Scripture, 223-41. Grand Rapids, MI: Eerdmans.

Johnson, W S 2006. A time to embrace: Same-gender relationships in religion, law, and politics. Grand Rapids, Ml: Eerdmans.

Louw, D J 1980. Die Bybel en homoseksualiteit, in Joubert, D et al, (reds), Perspektiewe op homoseksualiteit, 96-139. Durbanville: Boschendal.

Malick, D E 1993. The condemnation of homosexuality in Romans 1:26-27. Bibliotheca Sacra 150, 327-40.

Martin, D B 1995. Heterosexism and the interpretation of Romans 1:18-32. Biblical Interpretation 3(3), 332-55.

Moore, S D 1998. Que(e)rying Paul: Preliminary questions, in Clines, D J A \& Moore, S D (eds), Auguries: The Jubilee volume of the Sheffield Department of Biblical Studies, 250-274. Sheffield: Sheffield Academic Press. (JSOTSS 269.)

Neyrey, J H 1990. Paul in other words: A cultural reading of his letters. Louisville, KY: Westminster John Knox.

Nolland, J 2000. Romans 1:26-27 and the homosexuality debate. Horizons in Biblical Theology 22(1), 32-57.

Novak, D 2005. Talking with Christians: Musings of a Jewish theologian. Radical Traditions. Grand Rapids, MI: Eerdmans.

O'Grady, J F 2003. Postmodernism and the interpretation of Biblical texts for behavior. BTB 33(3), 95-103. 
Plaskow, J 2003. Authority, resistance, and transformation: Jewish feminist reflections on good sex, in Ellison, M M \& Thorson-Smith, S (eds), Body and soul: Rethinking sexuality as justice-love, 45-60. Cleveland, $\mathrm{OH}$ : Pilgrim.

Pregeant, R 1995. Engaging the New Testament: An interdisciplinary introduction. Minneapolis, MN: Fortress.

Punt, J 2007. Queer theory, postcolonial theory, and biblical interpretation: A preliminary exploration of some intersections. Biblical Interpretation (forthcoming).

Roetzel, C J 2003. Paul: A Jew on the margins. Louisville, KY: Westminster John Knox.

Sanders, E P 1992. s v Sin, sinners (New Testament), in Freedman, D N (ed), The Anchor Bible Dictionary, vol 6 (Si-Z), 40-47. New York: Doubleday.

Schotroff, L [1989] 1995. Lydia's impatient sisters: A feminist social history of Early Christianity, tr by B Rumscheidt \& M Rumscheidt. Louisville, KY: W J K.

Scroggs, R 1983. The New Testament and homosexuality: Contextual background for contemporary debate. Philadelphia, PA: Fortress.

Smith, M D 1996. Ancient bisexuality and the interpretation of Romans 1:26-27. JAAR 64(2), 223-256.

Stegemann, W 1993. Paul and the sexual mentality of his world. BTB 23(4), 161-166.

Stott, J 1984. Issues facing Christians today. Basingstoke: Marshalls.

Stowers, S K 1994. A rereading of Romans: Justice, Jews, and Gentiles. New York: Yale University Press.

Stowers, S K 2003. Paul and self-mastery, in Sampley, J P (ed), Paul in the GrecoRoman World: A Handbook, 524-50. Harrisburg, PA: Trinity Press International.

Swancutt, D M 2003. The disease of effemination: The charge of effeminacy and the verdict of God (Rom 1:18-2:16), in Moore, S D \& Anderson, J C (eds), New Testament masculinities, 193-233. Semeia Studies, vol 45. Atlanta, GA: SBL.

Swancutt, D 2004. Sexy stoics and the rereading of Romans 1.18-2:16, in Levine, A \& Blickenstaff, M (eds), A feminist companion to Paul, 42-73. Feminist companion to the New Testament and Early Christian Writings, vol 6. London: $T$ \& $T$ Clark.

Szesnat, H 1995. In fear of androgyny: Theological reflections on masculinity and sexism, male homosexuality and homophobia, Romans 1:24-27 and Hermeneutics (a response to Alexander Venter). JTSA 93, 32-50.

Thiselton, A C 2004. Can hermeneutics ease the deadlock?: Some Biblical exegesis and hermeneutical models, in Bradshaw, $\mathrm{T}$ (ed), The way forward?: Christian voices on homosexuality and the church, $145-96.2^{\text {nd }}$ ed. Grand Rapids, MI: Eerdmans.

Vorster, J N 2000. (E)mpersonating the bodies of Early Christianity. Neotestamentica 34(1), 103-124.

Ward, R B 1997. Why unnatural?: The tradition behind Romans 1:26-27. HTR 90(3), 263-84.

Webb, W J 2001. Slaves, women \& homosexuals: Exploring the hermeneutics of cultural analysis. Downers Grove, IL: IVP.

Westerholm, S 1997. Preface to the study of Paul. Grand Rapids, MI: Eerdmans.

Williams, R 2002. The body's grace. www.igreens.org.uk/bodys grace.htm

$(13 / 03 / 2007)$ 


\section{Romans 1:18-32 amidst the gay-debate}

White, L J 1995. Does the Bible speak about gays or same-sex orientation?: A test case in Biblical ethics: Part 1. BTB25(1), 14-23.

White, J L 1999. The apostle of God: Paul and the promise of Abraham. Peabody, MA: Hendrickson.

Wright, D F 1993. Homosexuality, in Hawthorne, G F, et al (et al), Dictionary of Paul and his letters, 413-415. Downers Grove, IL: IVP. 